\title{
Raising the $\mathrm{p} K_{\mathrm{a}}$ Limit of "Soft" Nucleophiles in Palladium- Catalyzed Allylic Substitutions. Application of Diarylmethane Pronucleophiles
}

\author{
Sheng-Chun Sha, Jiadi Zhang, Patrick J. Carroll, and Patrick J. Walsh \\ Roy and Diana Vagelos Laboratories, Department of Chemistry, University of Pennsylvania, 231 \\ South 34th Street, Philadelphia, Pennsylvania 19104-6323, United States
}

\begin{abstract}
The Tsuji-Trost allylic substitution reaction provides a useful and efficient approach to construct $\mathrm{C}-\mathrm{C}$ bonds between $\mathrm{sp}^{3}$-hybridized carbons. The widely accepted paradigm for classifying the mode of attack of nucleophiles on palladium $\pi$-allyl intermediates in the Tsuji-Trost reaction is based on the $\mathrm{p} K_{\mathrm{a}}$ of the pronucleophile: (1) stabilized or "soft" carbon nucleophiles and heteroatom nucleophiles (e.g., pronucleophiles with $\mathrm{p} K_{\mathrm{a}}$ 's $<25$ ), and (2) unstabilized or "hard" nucleophiles (those from pronucleophiles with $\mathrm{p} K_{\mathrm{a}}$ 's $>25$ ). One of the keys to the continuing development of allylic substitution processes remains broadening the scope of "soft" nucleophiles. Herein we report a general method for the room temperature Pd-catalyzed allylic substitution with diarylmethane derivatives ( $\mathrm{p} K_{\mathrm{a}}$ 's up to 32). The synthetic significance of the method is that it provides a rapid access to products containing allylated diarylmethyl motifs. The method is general for a wide range of nucleophiles derived from diarylmethanes and heterocyclic derivatives. A procedure for the Pd-catalyzed allylic substitutions to afford diallylation products with quaternary centers is also described. With triarylmethanes and, alkylated diarylmethanes the corresponding allylated products are isolated. We anticipate that the described method will be a valuable complement to the existing arsenal of nucleophiles in Pd-catalyzed allylic substitutions. Mechanistic studies show that the nucleophile derived from diphenylmethane undergoes external attack on $\pi$-allyl palladium species under our reaction conditions. This unexpected observation indicates that diarylmethane derivatives behave as "soft" or stabilized nucleophiles. The results of this study indicate that the cutoff between "soft" and "hard" nucleophiles should be raised from a pronucleophile $\mathrm{p} K_{\mathrm{a}}$ of 25 to at least 32 .
\end{abstract}

\section{INTRODUCTION}

Palladium-catalyzed C-C bond-forming reactions are among the most important and welldeveloped processes in modern organic chemistry. ${ }^{1-10}$ Of these, the Tsuji-Trost allylic substitution reaction provides a useful and efficient approach to construct $\mathrm{C}-\mathrm{C}$ bonds between sp3-hybridized carbons. As a result, it has been widely used to synthesize natural products and bioactive molecules. ${ }^{11-17}$ The widely accepted paradigm for classifying the mode of attack of nucleophiles on transition metal $\eta^{3}$ - $\pi$-allyl intermediates in the Tsuji-Trost reaction is based on the $\mathrm{p} K_{\mathrm{a}}$ of the pronucleophile. ${ }^{18}$ Nucleophiles are divided into two

Correspondence to: Patrick J. Walsh.

Corresponding Authorpwalsh@sas.upenn.edu.

ASSOCIATED CONTENT

Supporting Information

Procedures and full characterization of new compounds. This material is available free of charge via the Internet at http://pubs.acs.org

The authors declare no competing financial interest. 
classes: 1) stabilized or "soft" carbon nucleophiles and heteroatom nucleophiles (e.g., enolates and those from pronucleophiles with $\mathrm{p} K_{\mathrm{a}}$ 's $<25$ ), and (2) unstabilized or "hard" nucleophiles (those from pronucleophiles with $\mathrm{p} K_{\mathrm{a}}$ ' $\mathrm{s}>25$ ). The distinction between these two classes is "soft" nucleophiles directly attack the $\pi$-allyl moiety while "hard" nucleophiles first attack the metal center (via transmetallation) before bond formation with the allyl group. Importantly, these two pathways lead to distinct stereochemical outcomes (soft nucleophiles result in net retention in the Tsuji-Trost allylic substitution whereas hard nucleophiles react by single inversion). The scope of "soft" nucleophiles has received significant attention in asymmetric catalysis, ${ }^{11,13,14,19}$ although nonenantioselective Pdcatalyzed allylic substitution with "hard" nucleophiles are also known. ${ }^{20-22}$

One of the keys to the continuing development of allylic substitution processes remains broadening the scope of "soft" nucleophiles. With this in mind, Trost and co-workers increased the reach of "soft" nucleophiles in the allylic substitution with use of 2-picolinederived nucleophiles $\left(\mathrm{p} K_{\mathrm{a}}=34\right)^{23}$. Essential to their success was to increase the acidity of the 2-picoline $\mathrm{CH}_{3}$. This was accomplished by $\mathrm{BF}_{3}$ coordination to the pyridine nitrogen to facilitate deprotonation. The resulting "softened" nucleophile was successfully employed in Pd-catalyzed asymmetric allylic alkylation (AAA, Scheme 1A). ${ }^{18,24}$ The same group later reported no such activation was necessary with more acidic heterocycles, including pyrazine, pyrimidine, pyridazine, quinoxaline, and benzimidazole derivatives. (Scheme $1 \mathrm{~B})^{25}$

Our group recently introduced a strategy to employ toluene derivatives $\left(\mathrm{RC}_{6} \mathrm{H}_{4}-\mathrm{CH}_{2} \mathrm{R}, \mathrm{p} K_{\mathrm{a}}\right.$ $\sim 44)^{26}$ as "soft" pronucleophiles in Pd-catalyzed allylic substitution reactions using $\mathrm{Cr}(\mathrm{CO})_{3}$ to increase the acidity of the benzylic C-H's (Scheme 1C). ${ }^{27}$ The drawback of this approach is the stoichiometric use of chromium. We, therefore, set out to develop benzylic nucleophiles in the absence of chromium activating groups.

Application of unactivated diarylmethane derivatives as pronucleophiles in Pd-catalyzed allylic substitution reactions are unknown, but would have significant potential in medicinal chemistry. Hundreds of bioactive drug-like molecules contain allylated diarylmethyl motifs (Figure 1), with applications in treatment of breast cancer ${ }^{28}$, inhibitor of HIV protease ${ }^{29}$, blocker of human T-cells ${ }^{30}$ and antagonist of the thyroid hormone receptor, ${ }^{31}$ among others. Given these important applications, we set out to introduce diarylmethane-derived nucleophiles for the Pd-catalyzed allylic substitution. To achieve this objective, it is essential to find conditions to deprotonate diarylmethane derivatives that are compatible with the catalyst and substrates. Based on our previous studies on deprotonative crosscoupling processes (DCCP) using diarylmethane derivatives, ${ }^{32-35}$ we hypothesized that diarylmethane derivatives could be reversibly deprotonated in situ by $\mathrm{MN}\left(\mathrm{SiMe}_{3}\right)_{2}(\mathrm{M}=\mathrm{Li}$, $\mathrm{Na}, \mathrm{K})$ under mild conditions. These conditions would be more amenable to catalysis than deprotonation under traditional conditions with $n$-BuLi at low temperature. ${ }^{36}$ Herein we report an approach to the room temperature Pd-catalyzed allylic substitution with diarylmethane derivatives (Scheme 1D). This method enables rapid access to a variety of allylated products, including heteroaryl-containing derivatives as well as molecules bearing quaternary centers. The mild reaction conditions that have been identified employ $\mathrm{MN}\left(\mathrm{SiMe}_{3}\right)_{2}$ at room temperature and a Pd catalyst based on van Leeuwen's Xantphos ligand. ${ }^{37}$ Surprisingly, stereochemical studies indicate that nucleophiles derived from diarylmethane derivatives ( $\left.\mathrm{p} K_{\mathrm{a}}=25-33\right)^{26,38}$ behave as "soft" nucleophiles, significantly extending the range of nucleophiles undergoing the double inversion mechanism in the Tsuji-Trost allylic substitution. 


\section{RESULTS AND DISCUSSION}

As mentioned above, we recently disclosed a Pd-Xantphos catalyst system to promote the allylic substitution with $\mathrm{Cr}(\mathrm{CO})_{3}$-stabilized toluene-derived nucleophiles (eq 1). ${ }^{27} \mathrm{We}$ hypothesized the reaction conditions in eq 1 would be a good starting point for allylic substitution with diarylmethanes and related pronucleophiles.

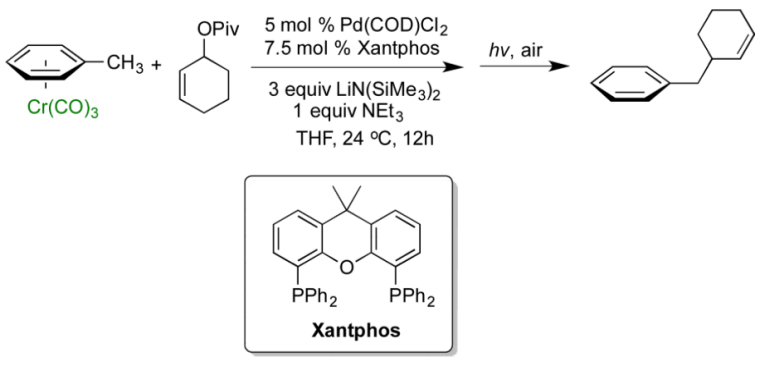

\subsection{Development and Optimization of Palladium-Catalyzed Allylic Substitution with Diarylmethanes}

Given the perceived challenge to the application of diphenylmethane $\left(\mathrm{p} K_{\mathrm{a}}=32.2\right)^{39}$ in allylic substitutions, we initiated our studies with the more acidic 2-benzylpyridine (1a, $\mathrm{p} K_{\mathrm{a}}$ $=28.2)^{38}$ under the reaction conditions in eq 1 . The desired product 3aa was formed in $80 \%$ assay yield (Table 1, entry 1). Switching the base to $\mathrm{NaN}\left(\mathrm{SiMe}_{3}\right)_{2}$ led to 3aa in $99 \%$ assay yield (entry 2). The additive $\mathrm{NEt}_{3}$, which proved very useful in eq 1 , was not necessary for the Pd-catalyzed allylic substitution with 2-benzylpyridine (entry 3 vs 2). The allylic substitution product formed with 2-benzylpyridine was isolated in $99 \%$ yield.

We next sought to increase the $\mathrm{p} K_{\mathrm{a}}$ of the pronucleophile. The less acidic 3-benzylpyridine (1c) $\left(\mathrm{p} K_{\mathrm{a}}=30.1\right),{ }^{38}$ however, led to only $27 \%$ assay yield (entry 4$)$. We increased the assay yield of $3 \mathbf{c a}$ to $70 \%$ by using the more reactive base, $\mathrm{KN}\left(\mathrm{SiMe}_{3}\right)_{2}$ (entry 5 ). Unfortunately, further decreasing the acidity of the pronucleophile was challenging: using diphenylmethane $\left(\mathbf{4 a a}, \mathrm{p} K_{\mathrm{a}}=32.3\right)^{39}$ gave desired product $\mathbf{5} \mathbf{a a}$ in only $10 \%$ assay yield (entry 6$)$. We next set out to optimize the reaction conditions for Pd-catalyzed allylic substitution with pronucleophiles with $\mathrm{p} K_{\mathrm{a}}$ 's $>30$, such as diphenylmethane.

From the results in Table 1, we hypothesized that the generation of the deprotonated diphenylmethane was problematic, and that choice of base would significantly impact the conversion. Since the traditional protocols preparing allylated diarylmethanes require strong bases (such as $n$-BuLi) at low temperature ${ }^{36}$ or under other harsh reaction conditions ${ }^{40}$, we limited ourselves to use of $\mathrm{KN}\left(\mathrm{SiMe}_{3}\right)_{2}$ as the strongest base in this study. We then screened different ethereal solvents (THF, 2-methyl THF, 1,4-dioxane, DME and CPME) and found that DME was the leading solvent of those examined (Table 2, entry 2, see the Supporting Information for details). Another important variable in optimizing Pd-catalyzed allylic substitution with diphenylmethane is the ratio of reagents. We observed decomposition of allyl tert-butyl carbonate 2a during the reaction. Increasing 2a to 3 equiv led to significant improvement in yield (entry 3 ). In addition, increasing the concentration of base led to higher concentrations of the nucleophile and improved yields (entries 4-5). Under these conditions, the allylic substitution product 5aa was obtained in 95\% isolated yield in DME with diphenylmethane $\mathbf{4 a}$ as the limiting reagent, 5 equiv of $\mathrm{KN}\left(\mathrm{SiMe}_{3}\right)_{2}$ and 3 equiv of the allyl electrophile $\mathbf{2 a}$. The yield dropped if the equivalence of $\mathbf{2 a}$ (entry 6 ) or the catalyst 
loading (entry 7) were decreased. With the optimized conditions in Tables 1 and 2, we examined various benzylic heterocycles and diarylmethanes as pronucleophiles in the allylic substitution.

\subsection{Scope of Heterocyclic Diarylmethanes in Palladium-Catalyzed Allylic Substitution}

Based on the optimization process above, we anticipated that the choice of base would be critical to expand the scope of pronucleophiles and that each substrate class might require reexamination of bases. We first evaluated the scope of heterocyclic diarylmethanes as pronucleophiles in Pd-catalyzed allylic substitution (Table 3). The diarylmethane derivatives containing heterocycles are interesting targets in medicinal chemistry. ${ }^{41-43}$ Our method provides a rapid access to the heteroaryl-containing allylated products in good to excellent yields using 1-5 mol \% catalyst loading (80-99\% yield). Silyl-amide bases, $\mathrm{MN}\left(\mathrm{SiMe}_{3}\right)_{2}$ $(\mathrm{M}=\mathrm{Li}, \mathrm{Na}, \mathrm{K})$, were used to accommodate the wide range of pronucleophile $\mathrm{p} K_{\mathrm{a}}$ 's. In general, $\mathrm{LiN}\left(\mathrm{SiMe}_{3}\right)_{2}$ was used for the most acidic pronucleophiles $\left(\mathrm{p} K_{\mathrm{a}}<28\right)$, $\mathrm{NaN}\left(\mathrm{SiMe}_{3}\right)_{2}$ for moderately acidic $\left(\mathrm{p} K_{\mathrm{a}}=28-31\right)$ and $\mathrm{KN}\left(\mathrm{SiMe}_{3}\right)_{2}$ for the least acidic $\left(\mathrm{p} K_{\mathrm{a}}\right.$ $>31$ ). The 2-, 4- and 3-benzylpyridines underwent allylation in 91-99\% yield (Table 3, entries 1-3). Xanthene (1d) derivatives are important components of dyes. ${ }^{44}$ Xanthene underwent monoallylation in $82 \%$ yield (entry 4). Furan ${ }^{45}$ and thiophene ${ }^{46}$ derivatives are valuable building blocks in agrochemicals and pharmaceuticals. Under the reaction conditions with $\mathrm{KN}\left(\mathrm{SiMe}_{3}\right)_{2}$ as the base, we observed decomposition of 2-benzylfuran (1e). Under the same reaction conditions with $\mathrm{NaN}\left(\mathrm{SiMe}_{3}\right)_{2}$ as the base, the desired product 3ea was obtained in only $32 \%$ yield. Using $\mathrm{NaN}\left(\mathrm{SiMe}_{3}\right)_{2}$, in combination with 15-crown-5 (2.5 equiv), the allylic substitution reaction afforded the desired product 3ea in $80 \%$ yield (entry 5 ). This result demonstrates that the use of additives, such as crown ethers, are useful in transition metal catalyzed processes other than deprotonative cross-coupling processes. ${ }^{32}$ With 2-benzylthiophene (1f) the desired substitution product 3fa was isolated in $93 \%$ with $\mathrm{NaN}\left(\mathrm{SiMe}_{3}\right)_{2}$ (entry 6). Di(3-pyridyl)methane (1g) was applied to give 3ga in $85 \%$ yield (entry 7). To establish the scalability of this method, the allylation of 3-benzylpyridine (1c) was examined on a $10 \mathrm{mmol}$ scale, affording the allylated product 3ca in $89 \%$ yield (eq 2).

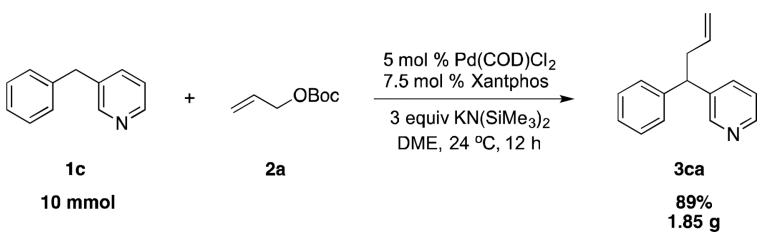

\subsection{Scope of Diphenylmethane Derivatives in the Allylic Substitution}

Diphenylmethane derivatives are more challenging pronucleophiles due to their higher $\mathrm{p} K_{\mathrm{a}}{ }^{\text {'s. }}{ }^{39}$ To compensate for the less favorable equilibrium for deprotonation of these pronucleophiles, the amount of base was increased to 5 equiv. With the optimized reaction conditions for 4a (Table 4, entry 1), we investigated 4-halogenated diphenylmethanes (entries 2-4). Compounds containing fluorine are important because of their bioactivities and uses in material science. ${ }^{47}$ The reaction with 4-fluoro diphenylmethane (4b) as pronucleophile afforded the desired product $\mathbf{5 b a}$ in $84 \%$ yield (entry 2). We then applied our reaction conditions to 4-bromo and 4-chloro diphenylmethanes $(\mathbf{4 c}$ and $\mathbf{4 d})$. A potential problem with these substrates lies in the competing oxidative addition of $\mathrm{C}-\mathrm{X}(\mathrm{X}=\mathrm{Cl}, \mathrm{Br})$ bonds to the active $\mathrm{Pd}(0)$ species. We were pleased to find that Pd-catalyzed allylic substitution afforded the allylated products $\mathbf{5} \mathbf{c a}$ and $\mathbf{5 d a}$ in $95 \%$ and $73 \%$ yield, respectively 
(entries 3 and 4). These results suggest that generation of the $\pi$-allyl palladium intermediate is significantly faster than the oxidative addition of $\mathrm{C}-\mathrm{X}$ bonds to the $\mathrm{Pd}(0)$ species under our reaction conditions. Fluorene (4e) derivatives have interesting characteristics and can be used in organic lightemitting diodes. ${ }^{44}$ By using 1.5 equiv $\mathrm{LiN}\left(\mathrm{SiMe}_{3}\right)_{2}$ and 1.1 equiv of $\mathbf{2 a}$, 5ea was generated in $87 \%$ yield (entry 5). 4-Cyano diphenylmethane (4fa) is potentially problematic because benzonitriles are known to undergo additions with strong bases and organometallic reagents. ${ }^{48}$ Nonetheless, this substrate provided the product $\mathbf{5 f a}$ in $90 \%$ yield (entry 6). As might be anticipated, pronucleophiles with electron donating groups are less acidic and, therefore, more difficult to deprotonate. We found that 4-methyl diphenylmethane $\mathbf{4 g}$ underwent substitution to give $5 \mathrm{ga}$ in $68 \%$ yield at $50{ }^{\circ} \mathrm{C}$ (entry 7 ). Notably, 2-methyl diphenylmethane $(\mathbf{4 h})$ reacted to provide 5 ha in $70 \%$ yield at $50{ }^{\circ} \mathrm{C}$ (entry 8). Unfortunately, 4-methoxy diphenylmethane did not react under these, or a variety of other conditions.

\subsection{Diallylation with Heteroaryl Diarylmethanes}

Having demonstrated the monoallylation of diarylmethanes and heteroaryl-containing derivatives, we next explored the possibility of adding a second allyl group to the allylated products prepared above. We were encouraged by the formation of small amounts of diallylation products with more acidic pronucleophiles $\left(\mathrm{p} K_{\mathrm{a}}<30\right)$ in the monoallylation optimization process. We, therefore, reoptimized the conditions to enable allylation of the purified monoallylated products. By employing 5 equiv of $\mathrm{KN}\left(\mathrm{SiMe}_{3}\right)_{2}$ and 3 equiv of $\mathbf{2 a}$ with the monoallylated substrates (3aa-3ga, Table 3), we obtained the corresponding diallylation products (6aa-6ga, 70-95\% yield). These results indicate that the allylation chemistry outlined here can be used to establish quaternary centers.

A more efficient method to prepare the diallylated products would be from the diarylmethane derivatives. We, therefore, set out to develop a one-pot diallylation protocol. We rationalized that the conditions mentioned above for the allylation of the mono-allylated diarylmethanes would be suitable for the one-pot diallylation. This approach proved fruitful: the yields for the double allylation ranged from 65 to $85 \%$ (Table 5, entries 1-5). The onepot syntheses were not efficient for 2-benzylpyridine (1a) and 3-benzylpyridine (1c) as pronucleophiles, because the deprotonation events are more difficult for these substrates. Nonetheless, starting from monoallylation products 3aa and 3ca we obtained the bisallylated products 6aa and 6ca in 84 and $80 \%$ yield (entries 6-7). We were also able to use 1,1-diarylethane (e.g., 8a) as pronucleophile to install an allyl group to afford a quaternary stereocenter (entry 8). Notably, triphenylmethane (9a) was used as pronucleophile to give the sterically congested 9aa in 90\% yield (entry 9). To summarize, our method afforded diaryl-or triarylmethane products containing at least one allyl group on the quaternary carbon. Some of the products in Table 5 could presumably be employed in ring-closing metathesis reactions ${ }^{49}$ to prepare 1,1-diarylcyclopent-3-ene or Pauson-Khand type $[2+2+1]$ reactions ${ }^{50}$ to afford bicyclic scaffolds.

\subsection{Scope of Electrophiles in Palladium-Catalyzed Allylic Substitutions}

Having demonstrated that the simplest allyl electrophile can be used with a variety of pronucleophiles, we turned our attention to the nature of the electrophilic partner. We chose the more acidic pronucleophile di(3-pyridyl)methane (1g, Table 3, entry 7) and examined the influence of different leaving groups on Pd-catalyzed allylic substitution with cyclohexenyl electrophiles $(\mathbf{2 b}, \mathbf{2} \mathbf{c})$. Both the Boc (2b) and benzoate ester (2c) derivatives gave similar yields of 10a ( 89 and $90 \%$ yield, entries 1-2). Changing the ring size of the electrophile from six to five (2d) resulted in 90\% yield (entry 3) when the Boc analogue was used. The classic 1,3-diphenyl allyl precursor $\mathbf{2 e}$ afforded the allylic substitution product 10c in $87 \%$ yield with a 10:1 trans:cis ratio (entry 4 ). 
Next, the less acidic diphenylmethane (4a) was employed as pronucleophile (entries 5-7). The Boc derived cyclohexenyl substrate $\mathbf{2 b}$ underwent reaction leading to the product in $85 \%$ yield (entry 5 ). In contrast, the benzoate derivative $2 \mathbf{c}$ resulted in only $20 \%$ yield (entry 6 ). The low yield is likely due to attack of nucleophile on the ester carbonyl. Changing the benzoate ester $\mathbf{2 c}$ to the pivalate ester $\mathbf{2 f}$ resulted in an increase in the yield to $70 \%$ (entry 7 ). Cyclopentenyl OBoc electrophile 2d underwent substitution in the presence of diphenylmethane in $94 \%$ yield (entry 8 ).

Many electrophilic partners used in allylic substitution reactions lead to unsymmetrical $\eta^{3}$ allyl groups. We, therefore, examined the regioselectivity with unsymmetrical linear Bocprotected electrophiles such as cinnamyl alcohol (2g), geranyl alcohol (2h) and prenyl alcohol (2i) (Table 6, entries 9-11). It is well known that $\pi$-allyl palladium complexes are prone to react with carbon nucleophiles at the less substituted terminus of the $\pi$-allyl.51 For the Pd-catalyzed allylic substitution with Boc-protected cinnamyl alcohol (2g), the linear product 10 f was the major product, albeit with moderate regioselectivity (2.6:1, entry 9). The reduced regioselectivity in this case, relative to cases with less basic nucleophiles, is likely a manifestation of the high reactivity of the 4-benzylpyridine-derived nucleophile. ${ }^{27}$ Interestingly, the prenylation and geranylation exhibited opposite regioselectivities (entries 10-11). The Boc activated geranyl underwent reaction with 4-benzylpyridine slightly favoring the terminal substitution product (1.9:1.0, linear:branched). In contrast, the prenylation afforded the branched product 10h' with a linear:branched ratio of 1.0:4.5 (entry 11). We hypothesize that the origin of the regioselectivity in the prenylation is a result of the non-bonded interaction between the bulky, wide-bite angle Xantphos ligand and the more substituted carbon of the $\eta^{3}$-allyl. This interaction places a larger $\delta+$ partial charge on the more substituted terminus and, therefore, nucleophilic attack at this position prevails. The additional substituent $(=\mathrm{R})$ on the $\eta^{3}$-allyl in the geranylation causes this group to adopt a conformation positioning it anti to the bulky (Xantphos)Pd center (Figure 2). The substituent partially obstructs the nucleophilic attack at the more substituted terminus, resulting in a shift of the regioselectivity toward the less substituted carbon of the allyl.

\subsection{Internal vs. External Attack of Diarylmethane on $\pi$-Allyl Palladium Intermediate}

As outlined in the Introduction, nucleophiles in allylic substitutions can directly add to the $\pi$-allyl or to the metal in their reactions with $\left[\left(\eta^{3}-\text { allyl }\right) \mathrm{ML}_{n}\right]^{+}$intermediates. It is generally accepted that nucleophiles with conjugate acids of $\mathrm{p} K_{\mathrm{a}}<25$, classified as "soft" nucleophiles, undergo external attack on $\pi$-allyl palladium complexes. Soft nucleophiles, therefore, result in stereoretentive allylic substitutions reactions (via double inversion). ${ }^{52} \mathrm{On}$ the other hand, "hard" nucleophiles, those with $\mathrm{p} K_{\mathrm{a}}>25$ are proposed undergo attack on the metal center of the $\pi$-allyl palladium complexes (i.e., transmetallation) followed by reductive elimination to afford net inversion for the allylic substitution. ${ }^{53}$

To examine the mechanistic pathway of the reaction, di(3-pyridyl)methane (1g) was reacted with cis-disubstituted stereoprobe $\mathbf{2 j}$ (Scheme 2A) and afforded cis-product 11a in $90 \%$ isolated yield as a single diastereomer (determined by ${ }^{1} \mathrm{H}$ NMR spectroscopy). Reaction of the less acidic pronucleophile diphenylmethane $(\mathbf{4 a})\left(\mathrm{p} K_{\mathrm{a}}=32.3\right)$ with $\mathbf{2 \mathbf { j }}$ (Scheme 2B) similarly furnished the cis-product $\mathbf{1 1 b}$ as a single diastereomer (determined by ${ }^{1} \mathrm{H}$ NMR spectroscopy and single crystal $\mathrm{X}$-ray diffraction) in $88 \%$ yield. The results indicated both nucleophiles derived from di(3-pyridyl)methane (19) and diphenylmethane (4a) behave as "soft" nucleophiles and that the $\mathrm{p} K_{\mathrm{a}}$ limit for "soft" nucleophiles should be raised from 25 to 32 , a change of 7 orders of magnitude. 


\section{SUMMARY AND OUTLOOK}

Herein we have developed a general method for Pd-catalyzed allylic substitution with diarylmethane derivatives at room temperature. The synthetic significance of the method is that it provides a rapid access to products containing allylated diarylmethanyl motifs. The method is general for a wide range of nucleophiles derived diarylmethanes and heteroaryl derivatives. A tandem procedure for the Pd-catalyzed allylic substitutions to afford diallylation products with quaternary centers is also described. With alkylated diarylmethanes and triarylmethanes, the method is also efficient to afford the corresponding allylated products. We anticipate that the described method will be a valuable complement to the existing arsenal of nucleophiles in Pd-catalyzed allylic substitutions. Mechanistic studies show that diarylmethane derivatives behave as "soft" or stabilized nucleophiles. The nucleophile derived from diphenylmethane undergoes external attack on $\pi$-allyl palladium species under our reaction conditions. The results of this study indicate that the cutoff between "soft" and "hard" nucleophiles should be raised from a p $K_{\mathrm{a}}$ of 25 to at least 32 .

\section{EXPERIMENTAL SECTION}

Representative procedures are described herein. Full experimental details and characterization of all compounds are provided in the Supporting Information.

\subsection{General Methods}

All reactions were performed under nitrogen using oven-dried glassware and standard Schlenk or vacuum line techniques. Air- and moisture-sensitive solutions were handled under nitrogen and transferred via syringe. The solvents (DME and THF) were sparged for 20 min with dry $\mathrm{N}_{2}$ and dried using a commercial two-column solvent purification system comprising columns packed with neutral alumina. Unless otherwise stated, reagents were commercially available and used as purchased without further purification. Chemicals were obtained from Sigma-Aldrich, Acros, TCI America, Strem Chemicals or Matrix Scientific, and solvents were purchased from Fisher Scientific. The progress of the reactions was monitored by thin-layer chromatography using Whatman Partisil K6F $250 \mu$ m precoated 60 $\AA$ silica gel plates and visualized by short-wavelength ultraviolet light as well as by treatment potassium permanganate $\left(\mathrm{KMnO}_{4}\right)$ stain or iodine. Silica gel (230-400 mesh, Silicycle) was used for flash chromatography. The ${ }^{1} \mathrm{H}$ NMR and ${ }^{13} \mathrm{C}\left\{{ }^{1} \mathrm{H}\right\}$ NMR spectra were obtained using a Brüker AM-500 Fourier transform NMR spectrometer at 500 and 126 $\mathrm{MHz}$, respectively. Chemical shifts are reported in units of parts per million (ppm) downfield from tetramethylsilane (TMS), and all coupling constants are reported in hertz. The infrared spectra were obtained with KBr plates using a Perkin-Elmer Spectrum 100 Series FTIR spectrometer. High-resolution mass spectrometry (HRMS) data were obtained on a Waters LC-TOF mass spectrometer (model LCT-XE Premier) using chemical ionization (CI) or electrospray ionization (ESI) in positive or negative mode, depending on the analyte. Melting points were determined on a Unimelt Thomas-Hoover melting point apparatus and are uncorrected.

\subsection{General Procedure A: Palladium-Catalyzed Allylic Substitution with Heterocyclic Diarylmethanes Under Room Temperature}

An oven-dried $10 \mathrm{~mL}$ reaction vial equipped with a stir bar was charged with $\mathrm{NaN}\left(\mathrm{SiMe}_{3}\right)_{2}$ $(55 \mathrm{mg}, 0.30 \mathrm{mmol}, 3$ equiv) under a nitrogen atmosphere. A solution (from a stock solution) of $\mathrm{Pd}(\mathrm{COD}) \mathrm{Cl}_{2}$ (1.43 $\left.\mathrm{mg}, 0.0050 \mathrm{mmol}\right)$ and Xantphos (4.34 mg, $\left.0.0075 \mathrm{mmol}\right)$ in $1 \mathrm{~mL}$ of dry DME was taken up by syringe and added to the reaction vial. After stirring for 5 min at $24{ }^{\circ} \mathrm{C}, 2$-benzylpyridine $1 \mathrm{a}(16 \mu \mathrm{L}, 0.1 \mathrm{mmol}, 1$ equiv) was added to the reaction mixture followed by $\mathbf{2 a}(34 \mu \mathrm{L}, 0.2 \mathrm{mmol}, 2$ equiv). Note that the diarylmethanes or allyl- 
OBoc in a solid form was added to the reaction vial prior to $\mathrm{NaN}\left(\mathrm{SiMe}_{3}\right)_{2}$. The reaction mixture was stirred for $12 \mathrm{~h}$ at $24{ }^{\circ} \mathrm{C}$, quenched with two drops of $\mathrm{H}_{2} \mathrm{O}$, diluted with $3 \mathrm{~mL}$ of ethyl acetate and filtered over a pad of $\mathrm{MgSO}_{4}$ and silica. The pad was rinsed with additional ethyl acetate, and the solution was concentrated in vacuo. The crude material was loaded onto a silica gel column and purified by flash chromatography eluting with EtOAc/ hexanes.

\subsection{General Procedure B: Palladium-Catalyzed Allylic Substitution with Heterocyclic Diarylmethanes Under $50^{\circ} \mathrm{C}$}

An oven-dried $10 \mathrm{~mL}$ reaction vial equipped with a stir bar was charged with $\mathrm{KN}\left(\mathrm{SiMe}_{3}\right)_{2}$ (160 mg, $0.80 \mathrm{mmol}, 8$ equiv) under a nitrogen atmosphere. A solution (from a stock solution) of $\mathrm{Pd}(\mathrm{COD}) \mathrm{Cl}_{2}(1.43 \mathrm{mg}, 0.0050 \mathrm{mmol})$ and Xantphos $(4.34 \mathrm{mg}, 0.0075 \mathrm{mmol})$ in $1 \mathrm{~mL}$ of dry DME was taken up by syringe and added to the reaction vial. After stirring for 5 min at $24{ }^{\circ} \mathrm{C}$, 4-methyl diphenylmethane $4 \mathbf{g}(18.5 \mu \mathrm{L}, 0.1 \mathrm{mmol}, 1$ equiv) was added to the reaction mixture followed by $\mathbf{2 a}(51 \mu \mathrm{L}, 0.3 \mathrm{mmol}, 3$ equiv). The reaction mixture was stirred for $12 \mathrm{~h}$ at $50{ }^{\circ} \mathrm{C}$, quenched with two drops of $\mathrm{H}_{2} \mathrm{O}$, diluted with $3 \mathrm{~mL}$ of ethyl acetate, and filtered over a pad of $\mathrm{MgSO}_{4}$ and silica. The pad was rinsed with additional ethyl acetate and the solution was concentrated in vacuo. The crude material was loaded onto a silica gel column and purified by flash chromatography eluting with EtOAc/hexanes.

\subsection{General Procedure C: Palladium-Catalyzed Allylic Substitution with Heterocyclic Diarylmethanes Under $0^{\circ} \mathrm{C}$}

An oven-dried $10 \mathrm{~mL}$ reaction vial equipped with a stir bar was charged with $\mathrm{LiN}\left(\mathrm{SiMe}_{3}\right)_{2}$ (51 mg, $0.30 \mathrm{mmol}, 3$ equiv) under a nitrogen atmosphere. A solution (from a stock solution) of $\mathrm{Pd}(\mathrm{COD}) \mathrm{Cl}_{2}(1.43 \mathrm{mg}, 0.0050 \mathrm{mmol})$ and Xantphos $(4.34 \mathrm{mg}, 0.0075 \mathrm{mmol})$ in $1 \mathrm{~mL}$ of dry DME was taken up by syringe and added to the reaction vial. After stirring for 5 min at $0{ }^{\circ} \mathrm{C}$, 4-benzylpyridine $1 \mathbf{b}(16 \mu \mathrm{L}, 0.1 \mathrm{mmol}, 1$ equiv $)$ was added to the reaction mixture followed by Boc-protected cinnamyl alcohol $2 \mathrm{~g}(46 \mu \mathrm{L}, 0.2 \mathrm{mmol}, 2$ equiv). The reaction mixture was stirred for $12 \mathrm{~h}$ at $0{ }^{\circ} \mathrm{C}$, quenched with two drops of $\mathrm{H}_{2} \mathrm{O}$, diluted with $3 \mathrm{~mL}$ of ethyl acetate, and filtered over a pad of $\mathrm{MgSO}_{4}$ and silica. The pad was rinsed with additional ethyl acetate and the solution was concentrated in vacuo. The crude material was loaded onto a silica gel column and purified by flash chromatography eluting with EtOAc/ hexanes.

\section{Supplementary Material}

Refer to Web version on PubMed Central for supplementary material.

\section{Acknowledgments}

We thank the National Science Foundation [CHE-1152488] and the National Institutes of Health (NIGMS GM104349) for financial support. We are grateful to Prof. Per Ola Norrby for helpful discussions.

\section{REFERENCES}

1. Cárdenas DJ. Angew. Chem., Int. Ed. 2003; 42:384.

2. Netherton MR, Fu GC. Adv. Synth. Catal. 2004; 346:1525.

3. Frisch AC, Beller M. Angew. Chem., Int. Ed. 2005; 44:674.

4. Rudolph A, Lautens M. Angew. Chem., Int. Ed. 2009; 48:2656.

5. Jana R, Pathak TP, Sigman MS. Chem. Rev. 2011; 111:1417. [PubMed: 21319862]

6. Burger EC, Tunge JA. Org. Lett. 2004; 6:4113. [PubMed: 15496112]

7. Waetzig SR, Tunge JA. J. Am. Chem. Soc. 2007; 129:14860. [PubMed: 17988134] 
8. Behenna DC, Stoltz BM. J. Am. Chem. Soc. 2004; 126:15044. [PubMed: 15547998]

9. Behenna DC, Liu Y, Yurino T, Kim J, White DE, Virgil SC, Stoltz BM. Nat. Chem. 2012; 4:130. [PubMed: 22270628]

10. Trost BM, Xu J, Schmidt T. J. Am. Chem. Soc. 2009; 131:18343. [PubMed: 19928805]

11. Trost BM, Van Vranken DL. Chem. Rev. 1996; 96:395. [PubMed: 11848758]

12. Trost BM, Crawley ML. Chem. Rev. 2003; 103:2921. [PubMed: 12914486]

13. Trost BM. J. Org. Chem. 2004; 69:5813. [PubMed: 15373468]

14. Trost BM, Machacek MR, Aponick A. Acc. Chem. Res. 2006; 39:747. [PubMed: 17042475]

15. Lu Z, Ma S. Angew. Chem., Int. Ed. 2008; 47:258.

16. Watson IDG, Styler SA, Yudin AK. J. Am. Chem. Soc. 2004; 126:5086. [PubMed: 15099089]

17. Watson IDG, Yudin AK. J. Am. Chem. Soc. 2005; 127:17516. [PubMed: 16332104]

18. Trost BM, Thaisrivongs DA. J. Am. Chem. Soc. 2008; 130:14092. [PubMed: 18826305]

19. Trost BM, Toste FD. J. Am. Chem. Soc. 1999; 121:4545.

20. Castanet Y, Petit F. Tetrahedron Lett. 1979; 20:3221.

21. Keinan E, Roth Z. J. Org. Chem. 1983; 48:1769. and references therein.

22. Shukla KH, DeShong P. J. Org. Chem. 2008; 73:6283. [PubMed: 18616321]

23. Dewick, PM. Essentials of Organic Chemistry:For Students of Pharmacy, Medicinal Chemistry and Biological Chemistry. West Sussex, UK: John Wiley \& Sons, Ltd; 2006.

24. Trost BM, Thaisrivongs DA. J. Am. Chem. Soc. 2009; 131:12056. [PubMed: 19645450]

25. Trost BM, Thaisrivongs DA, Hartwig J. J. Am. Chem. Soc. 2011; 133:12439. [PubMed: 21770467]

26. Bordwell FG, Bares JE, Bartmess JE, Drucker GE, Gerhold J, McCollum GJ, Van Der Puy M, Vanier NR, Matthews WS. J. Org. Chem. 1977; 42:326.

27. Zhang J, Stanciu C, Wang B, Hussain MM, Da C-S, Carroll PJ, Dreher SD, Walsh PJ. J. Am. Chem. Soc. 2011; 133:20552. [PubMed: 22047504]

28. Das B, Reddy CR, Kashanna J, Mamidyala SK, Kumar CG. Med. Chem. Res. 2011; 21:3321.

29. Craig C. 2-Aminothiazole Compounds Useful as Aspartyl Protease Inhibitors. 2005 WO2005US10224.

30. Burgess LE, Koch K, Cooper K, Biggers MS, Ramchandani M, Smitrovich JH, Gilbert EJ, Bruns MJ, Mather RJ, Donovan CB. Bioorg. Med. Chem. Lett. 1997; 7:1047.

31. Yoshihara HA, Apriletti JW, Baxter JD, Scanlan TS. Bioorg. Med. Chem. Lett. 2001; 11:2821. [PubMed: 11597408]

32. Bellomo A, Zhang J, Trongsiriwat N, Walsh PJ. Chem. Sci. 2013; 4:849.

33. Zhang J, Bellomo A, Creamer AD, Dreher SD, Walsh PJ. J. Am. Chem. Soc. 2012; 134:13765. [PubMed: 22816972]

34. Jia T, Bellomo A, Baina KE, Dreher SD, Walsh PJ. J. Am. Chem. Soc. 2013; 135:3740. [PubMed: 23419158]

35. Zheng B, Jia T, Walsh PJ. Org. Lett. 2013; 15:1690. [PubMed: 23517309]

36. Hajri M, Blondelle C, Martinez A, Vasse J-L, Szymoniak J. Tetrahedron Lett. 2013; 54:1029.

37. Kranenburg M, van der Burgt YEM, Kamer PCJ, van Leeuwen PWNM, Goubitz K, Fraanje J. Organometallics. 1995; 14:3081.

38. Bordwell FG. Acc. Chem. Res. 1988; 21:456.

39. Bordwell FG, Matthews WS, Vanier NR. J. Am. Chem. Soc. 1975; 97:442.

40. Cook JW, Moffatt JS. J. Chem. Soc. 1951:2487.

41. Hsin L-W, Dersch CM, Baumann MH, Stafford D, Glowa JR, Rothman RB, Jacobson AE, Rice KC. J. Med. Chem. 2002; 45:1321. [PubMed: 11882001]

42. Wai JS, Egbertson MS, Payne LS, Fisher TE, Embrey MW, Tran LO, Melamed JY, Langford HM, Guare JP, Zhuang L, Grey VE, Vacca JP, Holloway MK, Naylor-Olsen AM, Hazuda DJ, Felock PJ, Wolfe AL, Stillmock KA, Schleif WA, Gabryelski LJ, Young SD. J. Med. Chem. 2000; 43:4923. [PubMed: 11150161] 
43. Boyd RE, Rasmussen CR, Press JB, Raffa RB, Codd EE, Connelly CD, Li QS, Martinez RP, Lewis MA, Almond HR, Reitz AB. J. Med. Chem. 2001; 44:863. [PubMed: 11300868]

44. Griesbaum, K.; Behr, A.; Biedenkapp, D.; Voges, H-W.; Garbe, D.; Paetz, C.; Collin, G.; Mayer, D.; Höke, H. Hydrocarbons. Weinheim, Germany: Wiley-VCH Verlag GmbH \& Co. KGaA; 2000.

45. Hoydonckx, HE.; Van Rhijn, WM.; Van Rhijn, W.; De Vos, DE.; Jacobs, PA. Furfural and Derivatives. Weinheim, Germany: Wiley-VCH Verlag GmbH \& Co. KGaA; 2000.

46. Swanston, J. Thiophene. Weinheim, Germany: Wiley-VCH Verlag GmbH \& Co. KGaA; 2000.

47. Liu P, Sharon A, Chu CK. J. Fluorine Chem. 2008; 129:743.

48. Hou G, Gosselin F, Li W, McWilliams JC, Sun Y, Weisel M, O'Shea PD, Chen C-Y, Davies IW, Zhang X. J. Am. Chem. Soc. 2009; 131:9882. [PubMed: 19569686]

49. Kotha S, Manivannan E, Ganesh T, Sreenivasachary N, Deb A. Synlett. 1999; 10:1618.

50. Wender PA, Croatt MP, Deschamps NM. J. Am. Chem. Soc. 2004; 126:5948. [PubMed: 15137743]

51. For linear regioselectivity: Trost BM, Crawley ML. Chem. Rev. 2003; 103:2921-2944. [PubMed: 12914486] For branched regioselectivity in Pd-catalyzed AAA reactions: Trost BM, Crawley ML. Chem.-Eur. J. 2004; 10:2237. [PubMed: 15112213] Trost BM, Bunt RC, Lemoine RC, Calkins TL. J. Am. Chem. Soc. 2000; 122:5968. Trost BM, Toste FD. J. Am. Chem. Soc. 1999; 121:4545. Helmchen G, Pfaltz. A. Acc. Chem. Res. 2000; 33:336. Pretot R, Pfaltz A. Angew. Chem., Int. Ed. 1998; 37:323. You SL, Zhu XZ, Luo YM, Hou XL, Dai LX. J. Am. Chem. Soc. 2001; 123:7471.

[PubMed: 11472198] Zheng WH, Sun N, Hou XL. Org. Lett. 2005; 7:5151. [PubMed: 16268525]

Trost BM, Malhotra S, Chan WH. J. Am. Chem. Soc. 2011; 133:7328. [PubMed: 21520958]

52. Trost BM, Verhoeven TR. J. Org. Chem. 1976; 41:3215.

53. Matsushita H, Negishi E-I. J. Chem. Soc., Chem. Commun. 1982:160. 
<smiles>C=CCC(c1ccc(Cl)cc1)c1c(O)ccc2ccccc12</smiles>

Treatment of breast cancer<smiles>COc1ccc(CCCN2CCC(=CCC(c3ccccc3)c3ccccc3)CC2)cc1</smiles><smiles>C=CCC(c1ccc(I)cc1)c1csc(N)n1</smiles>

Inhibitor of HIV protease<smiles>C=CCC(c1ccc(O)c(C(C)C)c1)c1c(C)cc(OCC(=O)O)cc1C</smiles>

\section{Blocker of human T-cell}

\section{Antagonist of the thyroid hormone receptor}

Figure 1.

Selected bioactive compounds containing the allylated diarylmethyl motif. 

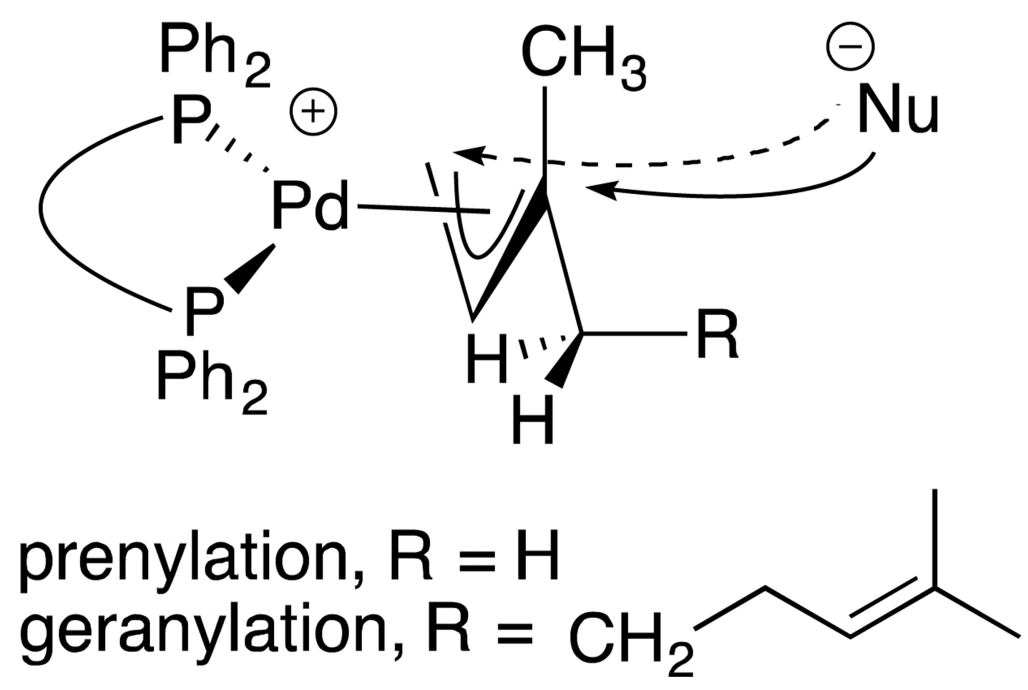

Figure 2.

Proposed conformational model to explain the reversal in regioselectivity between the prenylation and geranylation (Table 6 , entries $10-11$ ). When $\mathrm{R}=\mathrm{H}$ nucleophilic attack is favored at the more substituted terminus (solid arrow). When $\mathrm{R}=$ alkyl, attack follows the dashed arrow leading to the linear product. 


\section{A . 2-alkylpyridines}

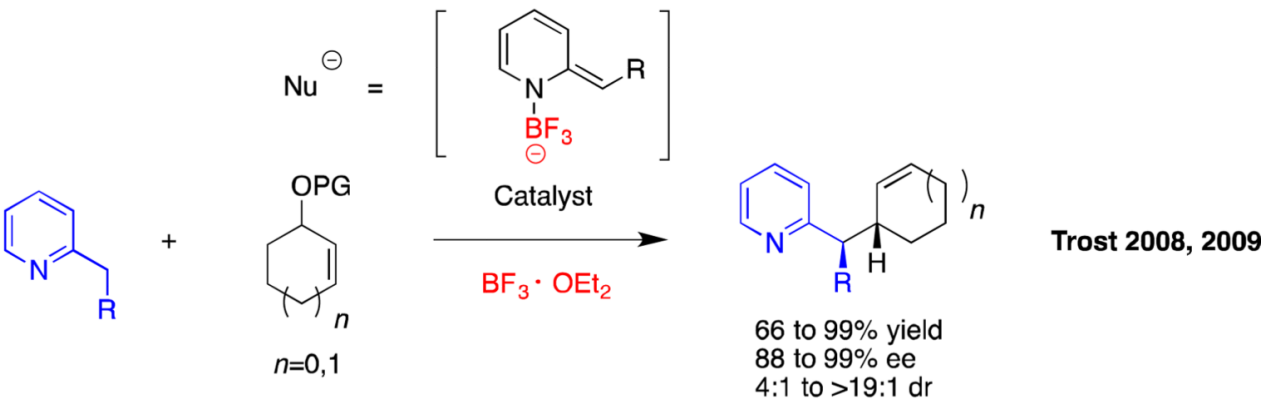

B. Polynitrogen-containing heterocycles

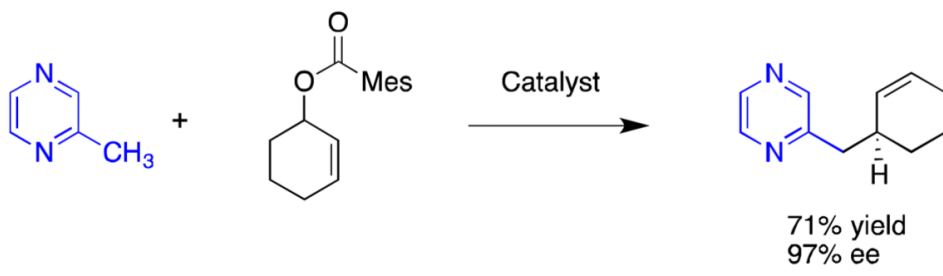

C. Chromium-stabilized toluene derivatives
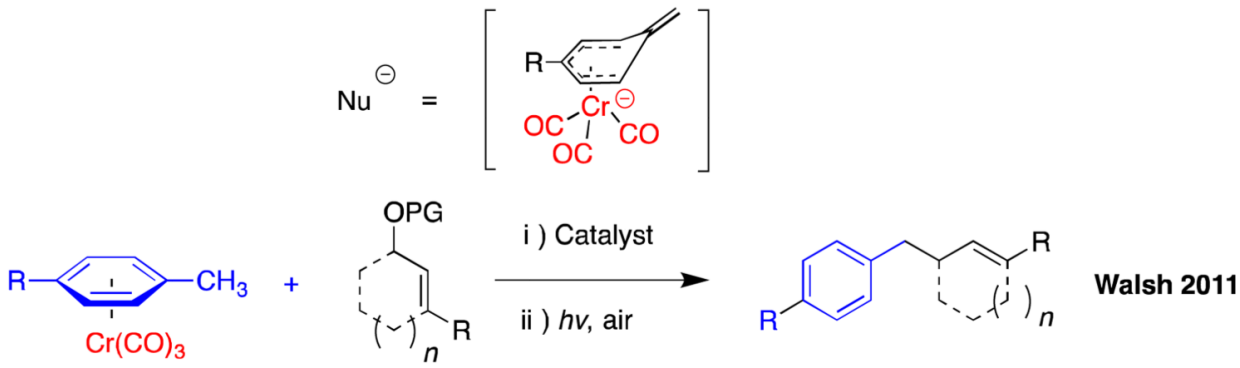

$$
n=0,1 \quad 45 \text { to } 99 \% \text { yield }
$$

D. This Work

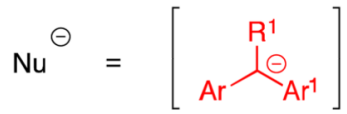

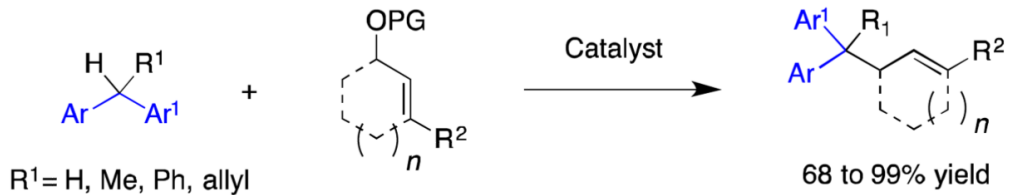

$\mathrm{p} K_{\mathrm{a}}$ up to $32 \quad n=0,1$

Scheme 1.

Palladium-Catalyzed Benzylic Allylations 


\section{A. Pd-catalyzed allylic substitution of $1 \mathrm{~g}$ with $2 \mathrm{j}$}<smiles></smiles>

$1 \mathrm{~g}$
$5 \mathrm{~mol} \% \mathrm{Pd}(\mathrm{COD}) \mathrm{Cl}_{2}$

$7.5 \mathrm{~mol} \%$ Xantphos

3 equiv $\mathrm{NaN}\left(\mathrm{SiMe}_{3}\right)_{2}$

DME, $24^{\circ} \mathrm{C}, 12 \mathrm{~h}$<smiles>C1=C[C@H](C(c2cccnc2)c2cccnc2)C[C@H](c2ccccc2)C1</smiles>

$11 a$ $90 \%$ yield

B. Pd-catalyzed allylic substitution of $4 a$ with $2 \mathrm{j}$<smiles></smiles>

$4 a$

$p K_{a}=32.3$
$5 \mathrm{~mol} \% \mathrm{Pd}(\mathrm{COD}) \mathrm{Cl}_{2}$

$7.5 \mathrm{~mol} \%$ Xantphos

5 equiv $\mathrm{KN}\left(\mathrm{SiMe}_{3}\right)_{2}$

DME, $24^{\circ} \mathrm{C}, 12 \mathrm{~h}$<smiles>C1=C[C@H](C(c2ccccc2)c2ccccc2)C[C@H](c2ccccc2)C1</smiles>

$11 \mathrm{~b}$ $88 \%$ yield

Scheme 2.

Allylic Substitution with Retention of Configuration 


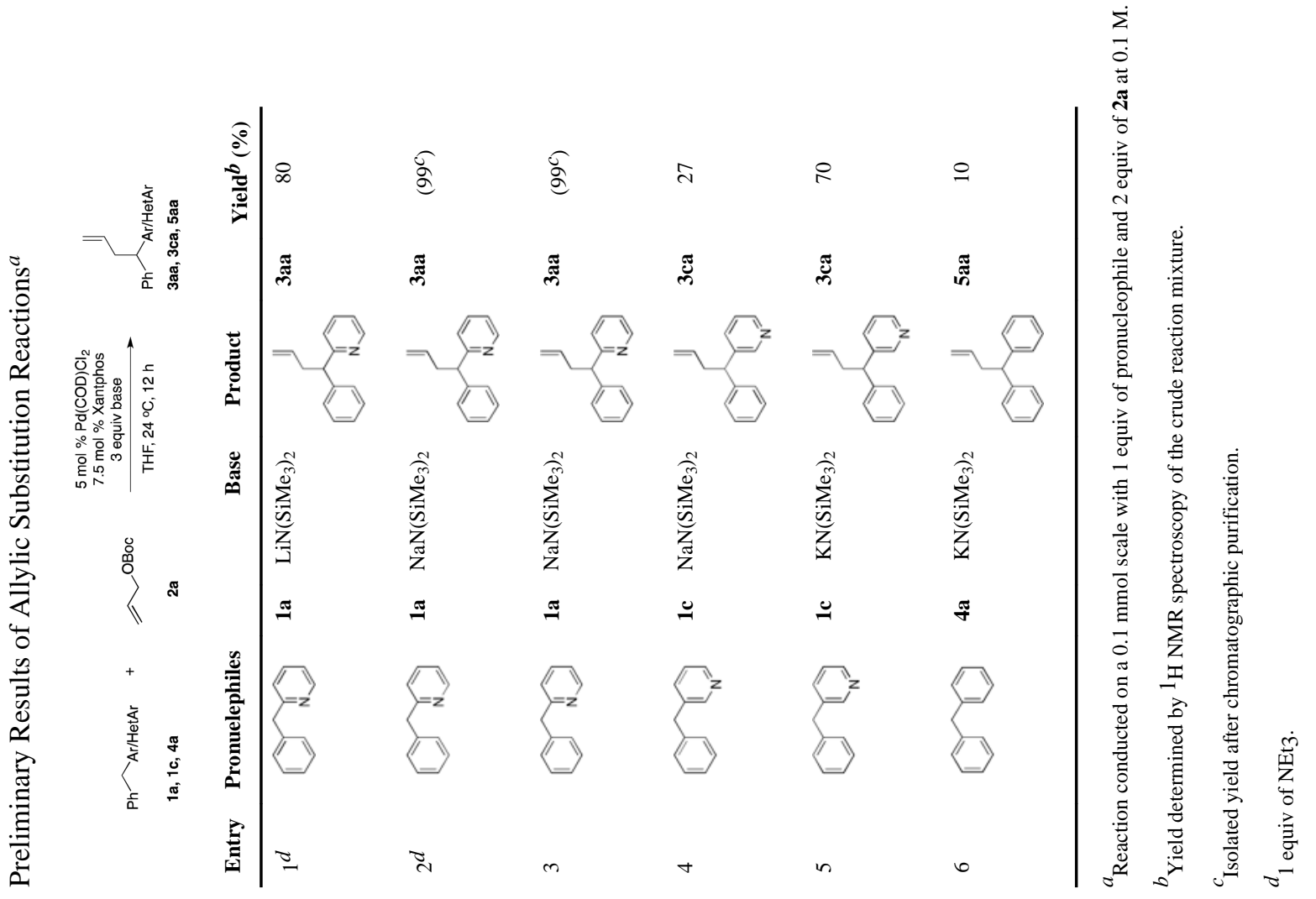


Table 2

Optimization of Allylic Substitution with Diphenyl-methane $\mathbf{4 a}^{a}$

\begin{tabular}{|c|c|c|c|}
\hline \multirow[b]{2}{*}{$4 a$} & \multirow[b]{2}{*}{$2 a$} & $\begin{array}{c}5 \mathrm{~mol} \% \mathrm{Pd}(\mathrm{COD}) \mathrm{Cl}_{2} \\
7.5 \mathrm{~mol} \% \text { Xantphos } \\
\mathrm{KN}\left(\mathrm{SiMe}_{3}\right)_{2}\end{array}$ & \\
\hline & & & 5 aа \\
\hline Entry & $\begin{array}{c}\text { Ratio } \\
\text { (4a:base:2a) }\end{array}$ & Solvent & $\operatorname{yield}^{b}(\%)$ \\
\hline 1 & $1: 3: 2$ & THF & 10 \\
\hline 2 & $1: 3: 2$ & DME & 55 \\
\hline 3 & $1: 3: 3$ & DME & 79 \\
\hline 4 & $1: 4: 3$ & DME & 88 \\
\hline 5 & $1: 5: 3$ & DME & $\left(95^{c}\right)$ \\
\hline 6 & $1: 5: 2$ & DME & 62 \\
\hline $7^{d}$ & $1: 5: 3$ & DME & 68 \\
\hline
\end{tabular}

${ }^{a}$ Reaction conducted on a $0.1 \mathrm{mmol}$ scale at $0.1 \mathrm{M}$.

${ }^{b}$ Yield determined by ${ }^{1} \mathrm{H}$ NMR spectroscopy of the crude reaction mixture.

$c_{\text {Isolated yield after chromatographic purification. }}$

$d_{2.5 \mathrm{~mol} \% \mathrm{Pd}(\mathrm{COD}) \mathrm{Cl}_{2} / 3.75 \mathrm{~mol} \% \text { Xantphos. }}$ 


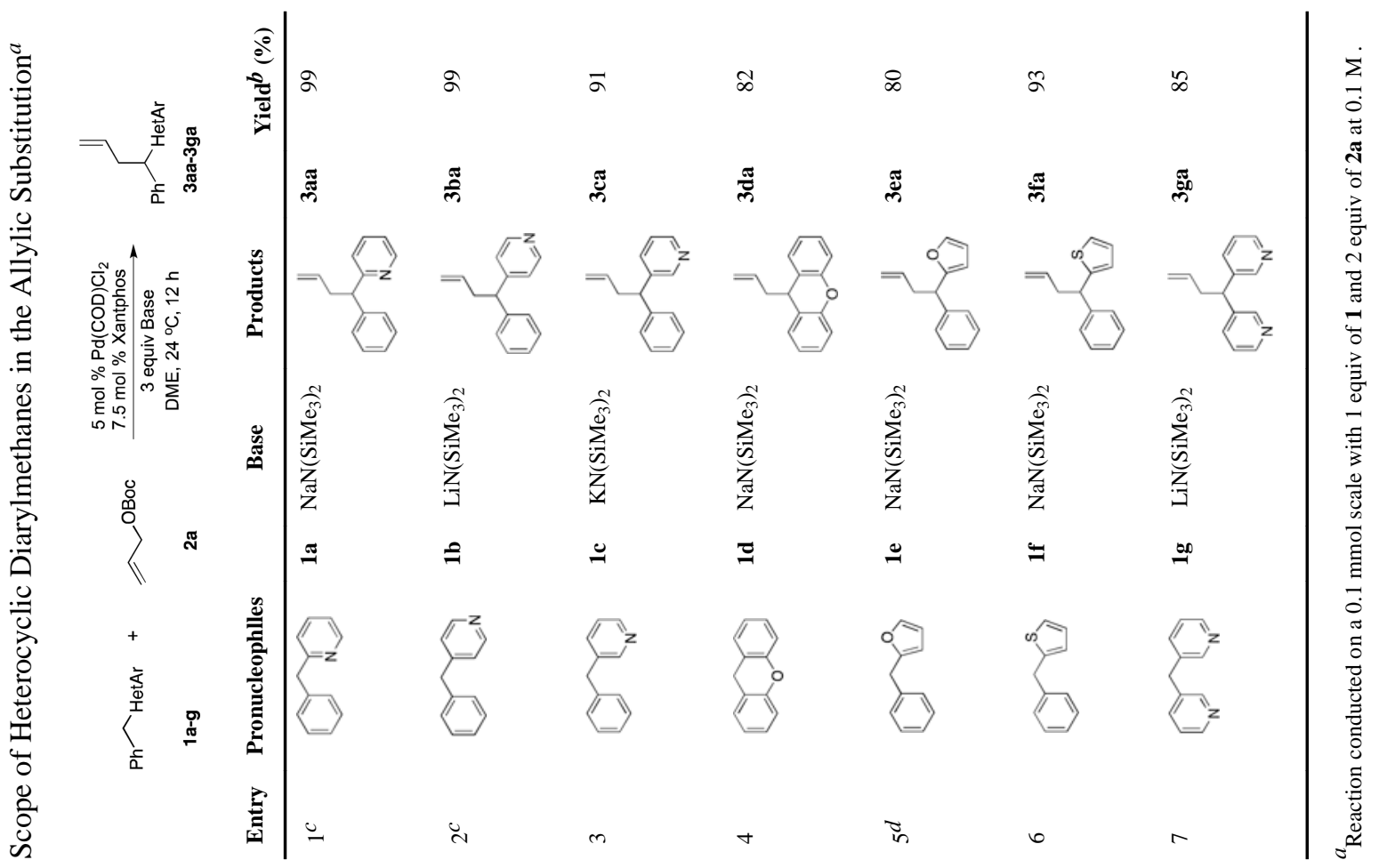




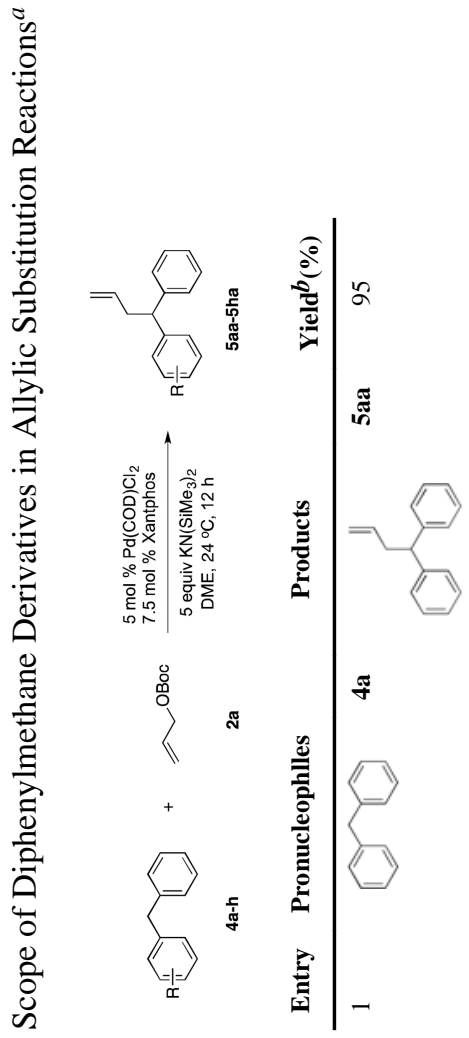

๖े

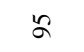

2

$\infty$

\& $\quad \infty$

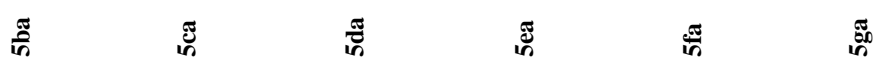
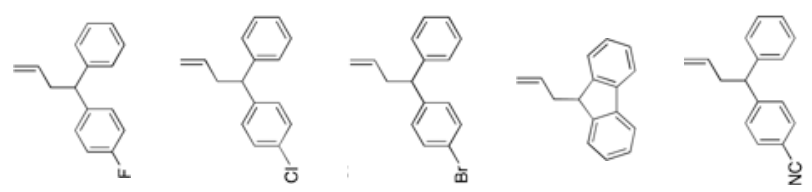

f $\quad \nsucceq$

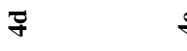

ษ
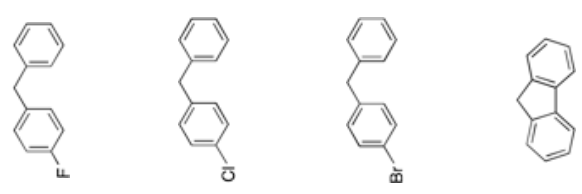

F
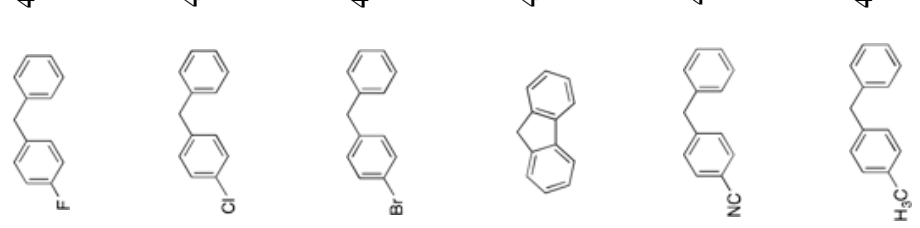

N

$m$

in

ซ

$\stackrel{\infty}{i}$ 


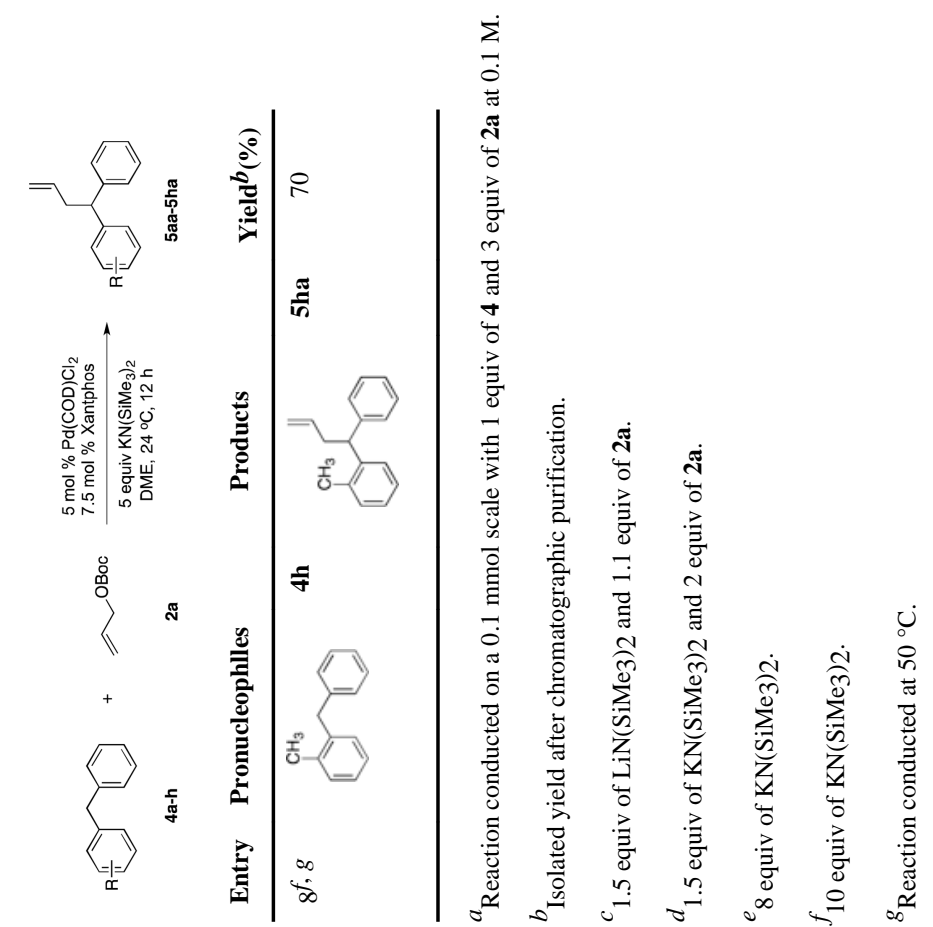


Table 5

Diallylation with Diarylmethanes $^{a}$

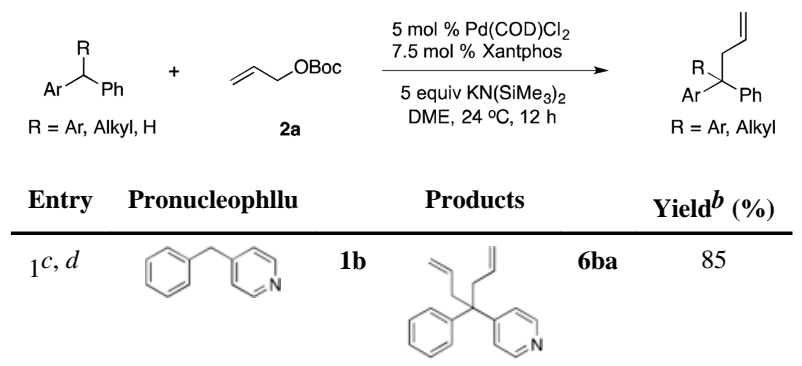

2

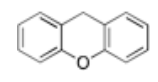

1d

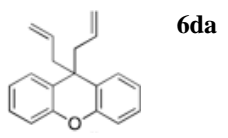

65

$3^{e}$

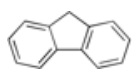

$4 e$

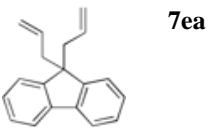

85

${ }_{4}^{f}$

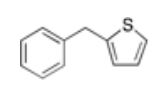

1f

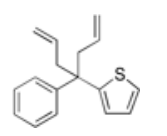

6fa

70

$5^{e}$

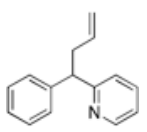

3aa

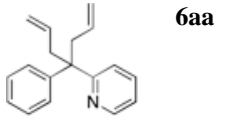

84

6

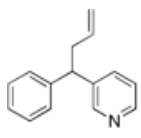

3ca

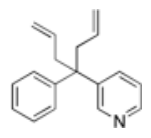

6ca

80

7

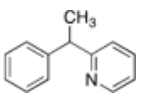

8a

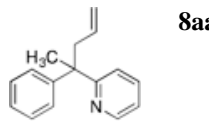

$8 a a$

90

8

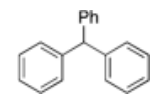

$9 a$

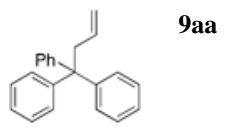

90

${ }^{a}$ Reaction conducted on a $0.1 \mathrm{mmol}$ scale with 1 equiv of pro-nucleophile and 3 equiv of $2 \mathbf{a}$ at $0.1 \mathrm{M}$.

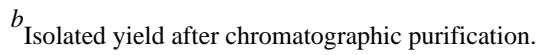

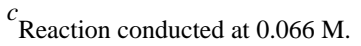

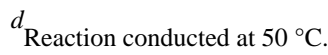

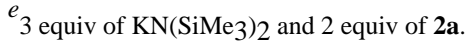

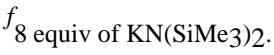




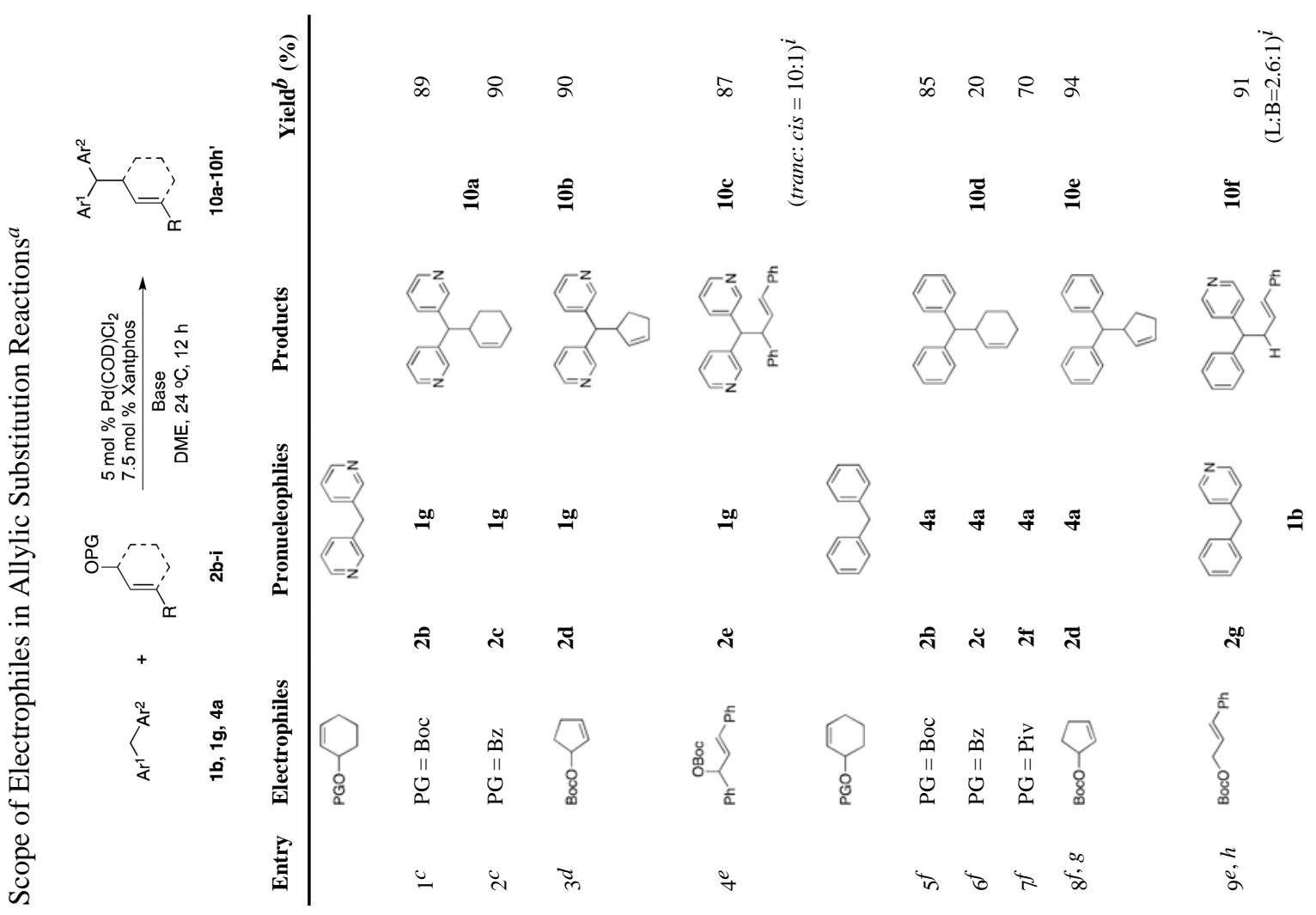




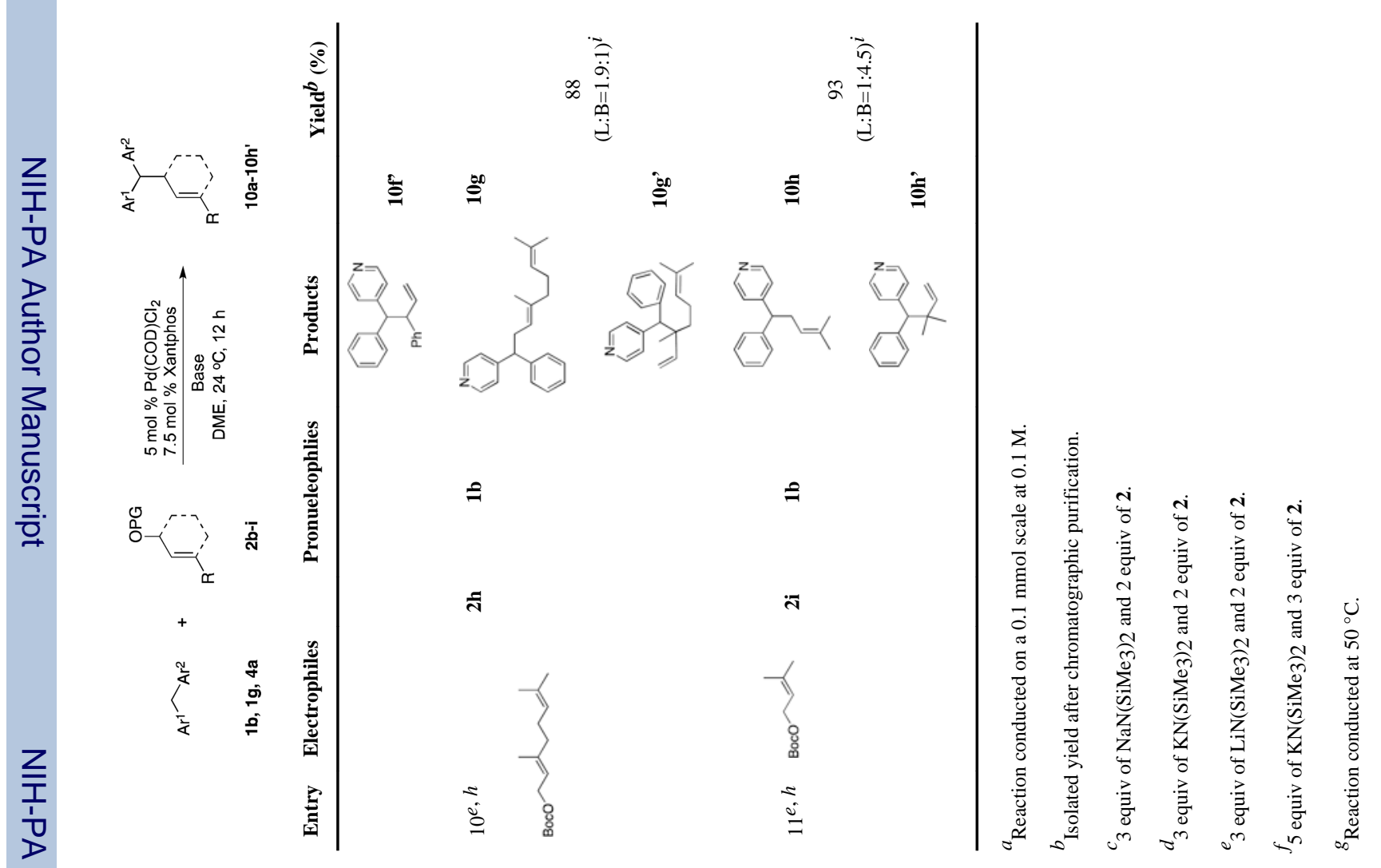


.

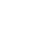

$$
\text { 范 }
$$$$
5
$$
氙 